(1)

\title{
Metformin increases hepatic leptin receptor and decreases steatosis in mice
}

\author{
Xuemei Tang 1,2,*, Jingwen Li1,2,*, Wei Xiang', Ye Cui², Bin Xie ${ }^{3}$, Xiaodong Wang 4 , \\ Zihui Xu² and Lixia Gan'1 \\ 1Department of Biochemistry and Molecular Biology, Third Military Medical University, Chongqing, China \\ 2Department of Integrated Medicine, Xinqiao Hospital, Third Military Medical University, Chongqing, China \\ 3Department of Hepatobiliary Surgery, Daping Hospital \& Institute of Surgery Research, Third Military \\ Medical University, Chongqing, China \\ 4Institute of Pathology, Southwest Hospital, Third Military Medical University, Chongqing, China \\ *(X Tang and J Li contributed equally to this work)
}

Correspondence should be addressed to $\mathrm{L}$ Gan or Z Xu Email

ganlixia@yahoo.com or zihuixu@yeah.net

\begin{abstract}
In addition to the ascertained efficacy as antidiabetic drug, metformin is increasingly being used as weight-loss agent in obesity, and as insulin sensitizer in nonalcoholic fatty liver disease (NAFLD). However, the mechanisms underlying these effects are still incompletely understood. Emerging evidence suggest metformin as leptin sensitizer to mediate the weight-loss effect in the brain. In this study, we investigated effects of metformin on expression of leptin receptors in liver and kidney in mice. C57BL/6 mice were fed with chow diet (CD) or high-fat diet (HF) for 5 months. Afterward, mice were treated with metformin $(50 \mathrm{mg} / \mathrm{kg}$ or $200 \mathrm{mg} / \mathrm{kg}$ ) for 15 days. Metabolic parameters and hepatic gene expression were analyzed at the end of the treatment. We also tested the effects of metformin on plasma-soluble leptin receptor (sOB-R) levels in newly diagnosed type 2 diabetes mellitus (T2DM) patients, and assessed its effect on hepatosteatosis in mice. Results showed that metformin upregulates the expression of leptin receptors (OB-Ra, -Rb, -Rc, and -Rd) in liver but not kidney. The stimulation effect is dosedependent in both chow and HF mice. Upregulation of OB-Rb, long signaling isoform, needs a relatively higher dose of metformin. This effect was paralleled by increased sOBR levels in mice and T2DM patients, and decreased hepatic triglyceride (TG) content and lipogenic gene expression, including sterol regulatory element-binding protein 1c (SREBP-1C), fatty acid synthase (FAS) and acetyl-CoA carboxylase-1 (ACC-1). Taken together, these data identify hepatic leptin receptor as target gene being upregulated by metformin which may enhance leptin sensitivity in liver to alleviate steatosis.
\end{abstract}

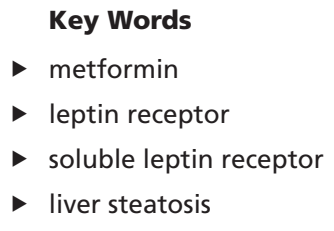

Journal of Endocrinology (2016) 230, 227-237

\section{Introduction}

Metformin is the first-line antihyperglycemia agent for T2DM patients. The mechanisms by which metformin improves glycemic control is mainly by reducing hepatic glucose production, and to a lesser extent, via enhancing
() 2016 Society for Endocrinology Printed in Great Britain peripheral insulin sensitivity, blocking gastrointestinal glucose absorption, modulating gut microbiota and promoting incretin axis (Ikeda et al. 2000, Green et al. 2006, Maida etal.2011, Miller etal.2013, Foretz etal.2014, 
Madiraju et al. 2014, Shin et al. 2014). In addition to its antidiabetic effects, metformin demonstrates multiple beneficial 'side effects' such as antiobesity, antihepatosteatotic and anti-inflammatory effects, and is currently in clinical trials to treat obesity (Malin \& Kashyap 2014), NAFLD (Zheng et al. 2015), polycystic ovary syndrome (PCOS) (Misso \& Teede 2015) and certain types of cancer (Leone et al. 2014, Morales \& Morris 2015). Emerging evidence suggests that enhanced leptin sensitivity may contribute to the weight-loss effect of this drug (Aubert et al. 2011, Malin \& Kashyap 2014). However, literature regarding metformin as leptin sensitizer is so far scarce.

Leptin is an adipocyte-derived hormone that exerts powerful effects both centrally and peripherally. In the brain, leptin inhibits food intake, promotes energy expenditure and regulates autonomic nerve control, thus playing a key role in body weight regulation (Zhang et al. 1994, Flak \& Myers 2016). In peripheral tissues, leptin directly acts on liver, muscle or pancreas to promote fat oxidation (Muoio \& Lynis Dohm 2002) or inhibiting insulin secretion (Marroquí et al. 2012). Mutations in the functional leptin $(\mathrm{ob} / \mathrm{ob})$ or leptin receptors gene $(\mathrm{db} / \mathrm{db})$ in mice and humans display abnormalities ranging from hyperphagia, diabetes, hypercortisolemia, infertility, cold intolerance to fatty liver and skeleton aberrations (Coleman 1982, Montague et al. 1997, Clément et al. 1998, Farooqi et al. 2007). Leptin replacement therapy reverses these abnormalities in leptin-deficient animals and patients. However, instead of lacking this hormone, most obese individuals (humans and animals) have elevated serum levels of leptin but with blunted response to the endogenous or exogenous leptin, a state which is defined as leptin resistance. Central leptin resistance plays a key role in pathogenesis of obesity (Caro et al. 1996, de Luca et al. 2005, Myers et al. 2010), while hepatic leptin resistance is a key determinant of lipid accumulation in liver (Fishman et al. 2007). Therefore, rescuing leptin sensitivity would provide opportunity to reverse obesityassociated diseases.

Leptin acts primarily by binding to a signaling leptin receptor, known as long isoform OB-Rb (Flak \& Myers 2016), whereas short receptor isoforms, OB-Ra,-Rc and-Rd, modulate leptin bioavailability and function via two mechanisms: control of leptin transport across the blood-brain barrier (BBB) (Kastin et al. 1999) and proteolytic cleavage production as sOBR, the major leptin-binding protein in circulation (Maamra et al. 2001, Ge et al. 2002). Much evidence indicate sOBR serve as a novel biomarker for leptin sensitivity. Decreased sOBR levels have been negatively correlated with increased obesity, serum leptin level, fasting plasma glucose (FPG), fasting insulin (FINs) and homeostasis model assessment of insulin resistance (HOMA-IR), biomarkers for hyperglycemia, leptin and insulin resistance (Ogawa et al. 2004, Hamnvik et al. 2011). However, increased sOBR levels have been positively correlated with high-density lipoprotein (HDL)-cholesterol and serum adiponectin levels (Ogawa et al. 2004, Hamnvik et al. 2011, Yu et al. 2011). In a recent large prospective study, increased plasma sOBR levels are associated with lowered risk of T2DM (Sun et al. 2010). In support, mice overexpressing sOB-R demonstrated reduced food intake, increased basal metabolic rate and increased lipid oxidation, metabolic phenotypes of higher leptin sensitivity (Lou et al. 2010). In agreement, liver-specific insulin receptor knockout (LIRKO) mice displays markedly increased sOBR levels in circulation and enhanced leptin sensitivity (Cohen et al. 2007). Moreover, obese subjects after weight loss surgery (Laimer et al. 2002, Siejka et al. 2013), diet therapy (Wolfe et al. 2004, Gajewska et al. 2013) or physical training (Balagopal et al. 2010, Gajewska et al. 2013) demonstrated increased sOBR levels, indicating the restoration in leptin sensitivity. Taken together, these studies implicate that manipulating sOBR levels may provide a therapeutic approach for rescue of leptin sensitivity.

Metformin has recently been shown to upregulate hypothalamic expression of $\mathrm{OB}-\mathrm{Rb}$ in rats (Aubert et al. 2011). Currently, it is unknown whether metformin upregulates peripheral expression of leptin receptors and sOBR levels. Given the fact that liver has a high abundance of leptin receptors (Brabant et al. 2004, Cohen et al. 2005), thus shedding of which produce the majority of plasma sOBR (Maamra et al. 2001, Ge et al. 2002). Therefore, in this study, we tested the effects of metformin on plasma sOB-R levels in T2DM patients and mice, and analyzed the expression of major isoforms of leptin receptor in mice liver and kidney, and assessed its effect on hepatosteatosis.

\section{Materials and methods}

\section{Patients ethical statement}

Informed written consent was obtained from the patients receiving metformin and accepting the collection of blood samples. This study protocol was approved by the Medical Ethics Committee in Xinqiao Hospital, the Third Military Medical University. Twelve newly diagnosed T2DM from May to November in 2013 were included. All of the patients underwent a thorough physical examination and

Published by Bioscientifica Ltd 
laboratory evaluation. Those with pregnancy, chronic diseases (cardiovascular, gastrointestinal and respiratory), a history of drug use (antibiotics, steroids, narcotics, antipsychotics, radioactive pharmaceuticals, toxic drugs for medical use and alcoholics), endocrine pathology (Cushing syndrome and hypothyroidism) and recent history of surgery were excluded from the study. These patients were given metformin treatment at $500 \mathrm{mg}$ each time for three times a day (a total of $1500 \mathrm{mg}$ /day) for a month, and then came back for plasma samples collection.

\section{Animal model}

All animal experiments were conducted in accordance with the Third Military Medical University guidelines for the care and use of laboratory animals and were approved by the University Animal Care and Use Committee. To set up an animal model with impaired glucose metabolism, C57BL/6 mice, all male, aged 4-6 weeks were randomized into two groups: one set of animals $(n=21)$ received standard chow diet (CD) and the other set $(n=21)$ a high-fat (HF) diet. Each group of mice was housed five per cage supplied with a normal rodent diet ad libitum in a pathogen free facility with a $12 \mathrm{~h}$ light: $12 \mathrm{~h}$ darkness cycle. The mice were fed the chow or HF diets for 5 months. Body weights were measured every 2 weeks. Fasting plasma glucose (FPG) was measured every month after depriving the mice from food overnight. Afterward, C57BL/6 mice were divided into six experimental groups and gavaged with metformin at $50 \mathrm{mg} / \mathrm{kg}$ or $200 \mathrm{mg} / \mathrm{kg}$ once a day for a continuous 15 days, with the saline gavaged mice as control as follows: (1) normal chow (CD-control, $n=7$ ); (2) normal chow + metformin $(50 \mathrm{mg} / \mathrm{kg} /$ day, $n=7)$; (3) normal chow + metformin (200 mg/kg/day, $n=7$ ); (4) high-fat diet (HF-control, $n=5$ ); (5) high-fat diet + metformin $(50 \mathrm{mg} / \mathrm{kg} /$ day, $n=6)$; (6) high-fat diet + metformin $(200 \mathrm{mg} / \mathrm{kg} /$ day, $n=7)$. At the end of treatment, mice were fasted overnight before sacrifice, and body weight, FPG, FINs, HOMA-IR and sOB-R levels were determined.

\section{Biochemical assays}

The blood samples from animals and patients were immediately put on ice, and plasma was centrifuged with EDTA-containing tubes at $1200 \boldsymbol{g}$ for $10 \mathrm{~min}$ at $4^{\circ} \mathrm{C}$. The plasma was spun again at $1200 \mathrm{~g}$ for $10 \mathrm{~min}$ at $4^{\circ} \mathrm{C}$, and the recovered plasma was stored in aliquots at $-70^{\circ} \mathrm{C}$. The EDTA-plasma was analyzed for glucose, insulin, total leptin (RIA; Linco Research) and SOB-R (ELISA; Diagnostic Systems Laboratories, Webster, TX, USA).

\section{Insulin sensitivity assessment}

Glucose and insulin tolerance tests were performed to assess the in vivo insulin sensitivity as we have described previously (Miao et al. 2014). Briefly, the mice were fasted overnight, and then given an i.p. injection of glucose (Sigma) ( $2 \mathrm{~g} / \mathrm{kg}$ body weight) in intraperitoneal glucose tolerance test (IPGTT) or an i.p. injection of insulin (Nanjing Pharmaceutical Co., China) (0.5 U/kg body weight) in insulin tolerance test (ITT). Blood samples were drawn from the tail vein immediately before the challenge, as well as 30, 60 and $120 \mathrm{~min}$ thereafter. HOMA-IR was used as an index of insulin resistance. HOMA-IR was calculated using the standard formula: fasting glucose $(\mathrm{mmol} / \mathrm{L}) \times$ FINs $(\mu \mathrm{U} / \mathrm{L}) / 22.5$.

\section{RNA isolation and real-time quantitative PCR}

Total RNA were extracted from each mouse liver using the RNAout reagent (TIANDZ Co., China) according to the manufacturer's protocol. The reverse transcription was performed using M-MLV reverse transcription kit (Invitrogen), as described previously (Miao et al. 2014). Real-time quantitative polymerase chain reaction (PCR) was performed with an Applied Biosystems PRISM 7500 Sequence Detector (Applied Biosystems), using the $\mathrm{IQ}_{\mathrm{TM}} \mathrm{SYBGreen} \mathrm{Supermix} \mathrm{(Bio-Rad} \mathrm{Laboratories).} \mathrm{The}$ primers used are listed in Table 1 . The PCR procedure was heat at $94^{\circ} \mathrm{C}$ for $5 \mathrm{~min}$ followed by 40 cycles of $95^{\circ} \mathrm{C}$ for $15 \mathrm{~s}$, $60^{\circ} \mathrm{C} 30 \mathrm{~s}$ and $72^{\circ} \mathrm{C} 30 \mathrm{~s}$. The level of the designated gene expression was expressed as the ratio of this gene relative to

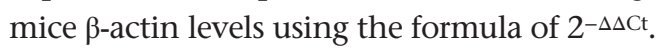

\section{Western blotting analysis}

Liver samples from experimental mice were processed to protein extraction and analyzed by Western blot. Antibodies against sheddase ADAM 10 (A disintegrin and metalloproteinase 10) and ADAM17 were incubated at $4^{\circ} \mathrm{C}$ overnight, followed by washing $5 \mathrm{~min}$ for three times with TBST (0.05\% Tween 20 in Tris-buffered saline, TBS) and incubation with horseradish peroxidase-conjugated secondary antibody (Zhongshan company Co, Beijing, China) for $2 \mathrm{~h}$ at room temperature. The membranes were

Published by Bioscientifica Ltd. 
Table 1 Real-time PCR primers for detection of leptin receptors and their shedding enzymes.

\begin{tabular}{|c|c|c|c|}
\hline Gene & GenBank (Access NO) & Primer (5' to $\left.3^{\prime}\right)$ & Product (bp) \\
\hline Mice-OB-Rt & NM_001032819.1 & $\begin{array}{l}\text { Forward: CAACACTGAAGGGAAGACACT } \\
\text { Reverse: CACTCTGTCCCAGTTTACA }\end{array}$ & 79 \\
\hline Mice-OB-Ra & U49106.1 & $\begin{array}{l}\text { Forward: AATGACGCAGGGCTGTATGT } \\
\text { Reverse: ATGGACTGTTGGGAAGTTGG }\end{array}$ & 194 \\
\hline Mice-OB-Rb & U49107.1 & $\begin{array}{l}\text { Forward: TGCTTTTGACTGGTGAGGCA } \\
\text { Reverse: CTGTGCGTGGAACAGGTTTG }\end{array}$ & 138 \\
\hline Mice-OB-Rc & U49108.1 & $\begin{array}{l}\text { Forward: CAAGCAGCAGAATGACGCAG } \\
\text { Reverse: GTGACCTTTTGGAAATTCAGTCCT }\end{array}$ & 133 \\
\hline Mice-OB-Rd & U49109.1 & $\begin{array}{l}\text { Forward: ACGCAGGGCTGTATGTCATT } \\
\text { Reverse: TCCTTTTGGAAATTCAGTCCTTG }\end{array}$ & 117 \\
\hline Mice-Adam 10 & NM_007399.3 & $\begin{array}{l}\text { Forward: TGGAGTAGAGGAAGGAGCCC } \\
\text { Reverse: CTTTCAGCCAGAGTTGTGCG }\end{array}$ & 96 \\
\hline Mice-Adam 17 & NM_009615.6 & $\begin{array}{l}\text { Forward: GTGCTGGGAAGATCACCTCC } \\
\text { Reverse: CACCACCTCTCTGGGAAACC }\end{array}$ & 81 \\
\hline Mice- $\beta$-actin & NM_007393.3 & $\begin{array}{l}\text { Forward: CTGTCCCTGTATGCCTCTG } \\
\text { Reverse: ATGTCACGCACGATTTCC }\end{array}$ & 218 \\
\hline
\end{tabular}

washed again as described above, and the bands were detected by chemiluminescence for visualization. $\beta$-actin was used as an internal control.

\section{Liver morphological analysis}

Small pieces of liver were fixed in a freshly prepared $4 \%$ paraformaldehyde in $0.1 \mathrm{M}$ phosphate buffer and processed into paraffin sections for hematoxylin and eosin staining and histopathological observation. The morphological changes of liver tissues were observed by two pathologists who were blinded from the experimental information.

\section{Liver triglycerides assay}

Quantitative analysis of liver TG content was performed by saponification of liver in ethanolic $\mathrm{KOH}$. After neutralization with $\mathrm{MgCl}_{2}$, TG levels were measured by a colorimetric method (Zhejiang Dongou Biotechnical Company, China) according to the manufacturer's instruction.

\section{ELISA assay for SOB-R}

ELISA analysis of plasma sOB-R levels using a mouse or human sOB-R ELISA kit (Huijia biotechnology, China) was carried according to manufacturer's instructions. This ELISA kit detects sOB-R and other OB-R molecules that contain the ectodomain of OB-R.

\section{Statistical analysis}

All results are expressed as the mean \pm s.e.m. Data were analyzed using a one-factor analysis of variance to compare the means of all groups. Between-two group differences in continuous variables were assessed by a univariate analysis with Student's t-test. Oneway ANOVA was used for the comparison of more than two groups, followed by Turkey-Kramer post hoc test. $P$-value $<0.05$ was considered to indicate statistical significance.

\section{Results}

\section{Metformin increases plasma soluble leptin receptor levels in humans and mice}

To detect the effects of metformin therapy on sOBR levels, the plasma samples from newly diagnosed T2DM patients were tested before and after metformin (1500 mg/day) for 1 month. As shown in Table 2, FPG, FINs, glycated albumin and leptin levels were significantly decreased, whereas sOB-R levels significantly increased in patients after metformin treatment compared with pretreatment values.

To investigate this drug effect in greater detail, we turned to metabolic-disturbed animal model by feeding mice with HF for 5 months. As shown in Fig. 1, HF-induced elevated FPG levels (Fig. 1B), insulin resistance index HOMA-IR (Fig. 1D), impaired glucose tolerance (Fig. 1E) and insulin tolerance (Fig. 1F) were compared with CD-fed mice, whereas, body weight (Fig. 1A) and FINs (Fig. 1C) were not significantly changed. These data demonstrate the presence of HF-induced metabolic disturbance.

Metformin was then administrated at a low $(50 \mathrm{mg} / \mathrm{kg} /$ day $)$ or high dose $(200 \mathrm{mg} / \mathrm{kg} /$ day $)$ for a

Published by Bioscientifica Ltd 
Table 2 Effects of metformin therapy on serum metabolic parameters and biomarkers in newly diagnosed T2DM patients.

\begin{tabular}{|c|c|c|c|}
\hline Variable & Before drug use & After drug use & P-value \\
\hline$n$ & 12 & 12 & \\
\hline \multicolumn{4}{|l|}{ Demography } \\
\hline Age (year) & $56.15 \pm 9.48$ & $56.15 \pm 9.48$ & NS \\
\hline \multicolumn{4}{|l|}{ Sex (no) } \\
\hline Female & 6 & 6 & NS \\
\hline Male & 6 & 6 & NS \\
\hline BMI $\left(k g / m^{2}\right)$ & $23.96 \pm 4.14$ & $23.52 \pm 3.08$ & NS \\
\hline Waist circumference $(\mathrm{cm})$ & $83.77 \pm 11.31$ & $83.48 \pm 10.59$ & NS \\
\hline Hip circumference $(\mathrm{cm})$ & $97.54 \pm 10.78$ & $96.79 \pm 10.63$ & NS \\
\hline Waist-to-hip ratio & $0.86 \pm 0.08$ & $0.86 \pm 0.06$ & NS \\
\hline \multicolumn{4}{|l|}{ Metabolism } \\
\hline Fasting plasma glucose (mmol/L) & $7.03 \pm 0.90$ & $6.11 \pm 0.73$ & $<0.05$ \\
\hline Fasting plasma insulin $(\mu \mathrm{U} / \mathrm{mL})$ & $13.84 \pm 6.04$ & $11.16 \pm 5.03$ & $<0.05$ \\
\hline \multicolumn{4}{|l|}{ Cholesterol levels (mmol/L) } \\
\hline Total & $4.10 \pm 0.95$ & $3.90 \pm 1.31$ & NS \\
\hline LDL & $2.99 \pm 0.52$ & $2.88 \pm 0.57$ & NS \\
\hline HDL & $1.32 \pm 0.28$ & $1.30 \pm 0.25$ & NS \\
\hline Triglycerides (mmol/L) & $1.58 \pm 0.72$ & $1.50 \pm 0.76$ & NS \\
\hline Uric acid $(\mu \mathrm{mol} / \mathrm{L})$ & $334.08 \pm 60.34$ & $321.96 \pm 67.64$ & NS \\
\hline \multicolumn{4}{|l|}{ Biomarker } \\
\hline HbAlc (\%) & $6.86 \pm 1.90$ & $6.68 \pm 1.80$ & NS \\
\hline Glycated albumin & $18.04 \pm 5.47$ & $15.15 \pm 5.77$ & $<0.05$ \\
\hline Soluble leptin receptor $(\mathrm{ng} / \mathrm{mL})$ & $15.82 \pm 1.71$ & $31.08 \pm 6.78$ & $<0.05$ \\
\hline Leptin $(\mathrm{ng} / \mathrm{mL})$ & $41.47 \pm 4.47$ & $24.03 \pm 1.94$ & $<0.05$ \\
\hline
\end{tabular}

Plus-minus values are mean \pm s.E.M. The body mass index (BMI) is the weight in kilograms divided by the square of the height in meters. HbAlC, glycosylated hemoglobin; NS, not significant.

consecutive 15 days. Results showed that treatment with this drug significantly decreased FPG (Fig. 2A), HOMA-IR (Fig. 2B) and improved glucose tolerance (Fig. 2E) in HF mice, while showed no significant effects in CD mice (Fig. 2A, B and D). Interestingly, serum sOBR levels significantly increased in both CD and HF mice with metformin treatment, and in a dose-dependent manner (Fig. 2C).

\section{Metformin upregulates leptin receptor expression in liver, but not in kidney}

Given the evidence from in vivo radioactive ligandbinding assay that more than $80 \%$ of leptin was bound in liver, and $17 \%$ of which in kidney (Brabant et al. 2004), we thus detected the expression of leptin receptors in the two organs. Results showed that total leptin receptor
A

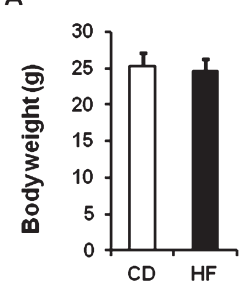

B
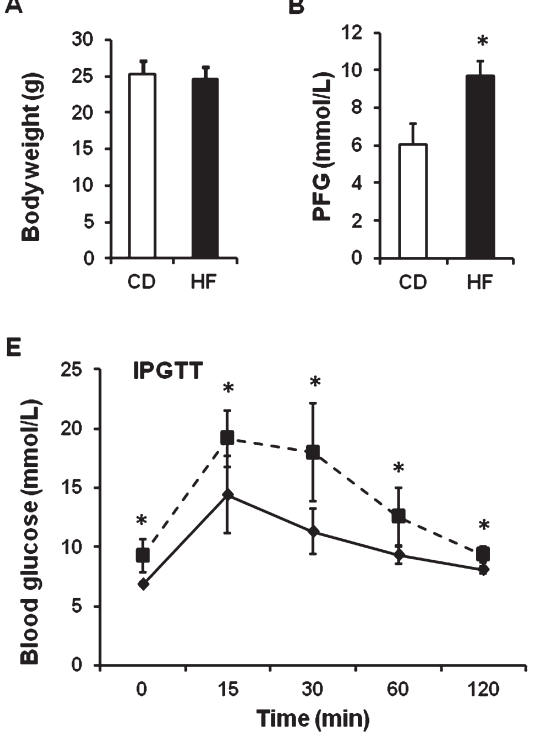

C

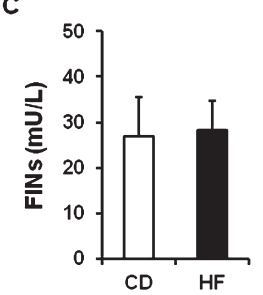

D

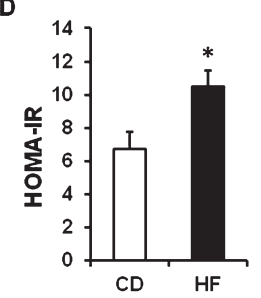

$\mathbf{F}$

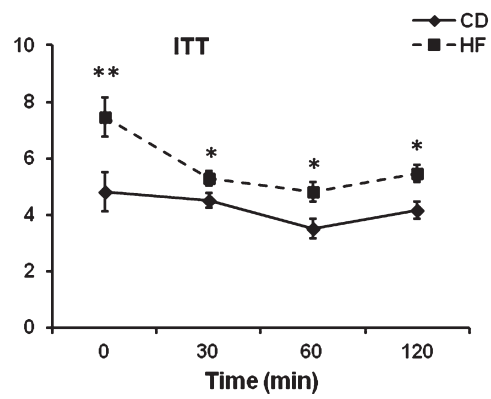

Figure 1

High-fat diet-induced metabolic disturbance in mice. Effects of high-fat diet on metabolic changes versus chow diet in male mice: $(A)$ body weights; (B) concentration of fasting plasma glucose (FPG); (C) fasting insulin (FINs); (D) the homeostasis model assessment of insulin resistance (HOMA-IR); (E) intraperitoneal glucose tolerance test (IPGTT) and (F) insulin tolerance test (ITT). The values are mean \pm S.E.M. ${ }^{*} P<0.05$ and $* * P<0.01$ between diet group (Chow vs HF). 
A

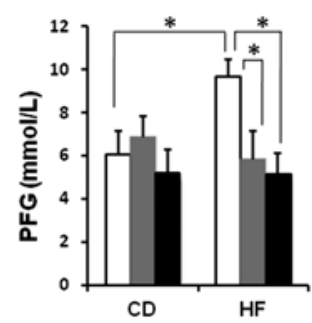

B

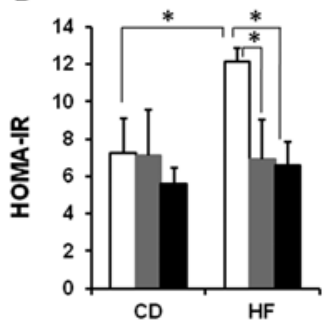

C

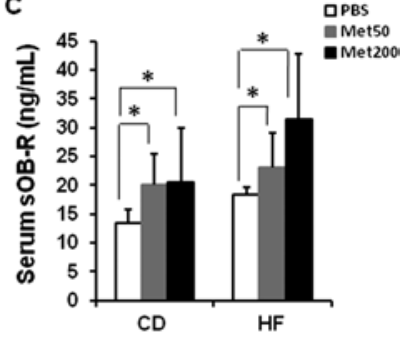

D

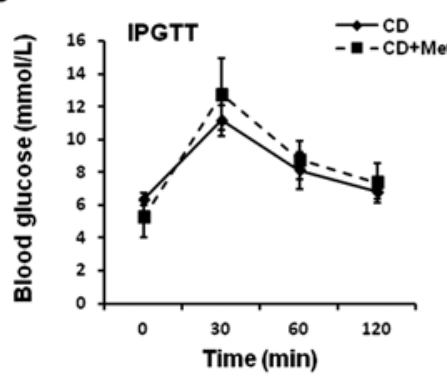

E

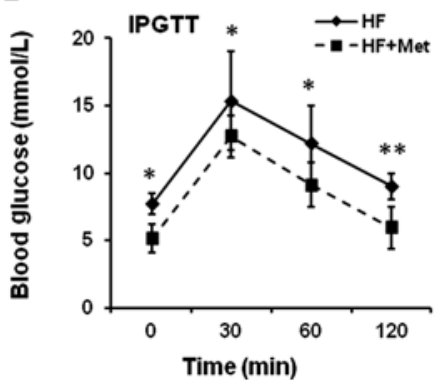

Figure 2

Metformin improved glucose metabolism in mice fed a high-fat diet. Effects of metformin for 15 days at designated concentration on male mice: (A) FPG; (B) HOMA-IR; (C) sOB-R levels and its effect on glucose disposal ability at $200 \mathrm{mg} / \mathrm{kg} /$ day; (D) IPGTT in CD mice and (E) IPGTT in HF mice. ${ }^{*} P<0.05$ and ${ }^{* *} P<0.01$.
(OB-Rt), measurement for the shared ectodomain region of this receptor, was significantly upregulated by metformin in liver, but not in kidney (Fig. 3A). As there are four membrane-anchored leptin receptor isoforms (OB-Ra, -Rb, -Rc and -Rd) in human, we subsequently measured the four homologous isoforms in mice. Results showed that metformin dose-dependently increases hepatic, but not renal, OB-Ra (Fig. 3C), -Rc (Fig. 3D) and -Rd (Fig. 3E) in both CD- and HF-mice. Worth to note is that only higher dose of this drug can increase OB-Rb expression (Fig. 3B), again in liver but not in kidney, in HF mice only.

\section{Metformin does not affect the expression of ADAM10 and ADAM17}

Two metalloproteases, ADAM 10 (A disintegrin and metalloproteinase 10) and ADAM17, are reported to participate in enzymatic cleavage of this receptor (Schaab et al. 2012). We detected the effect of metformin on ADAM 10 and ADAM17 expression in liver and kidney. Results showed no significant changes in the mRNA (Fig. 4A and B) or protein levels (Fig. 4C) of both enzymes in liver or kidney (data not shown) before or after metformin treatment.
A

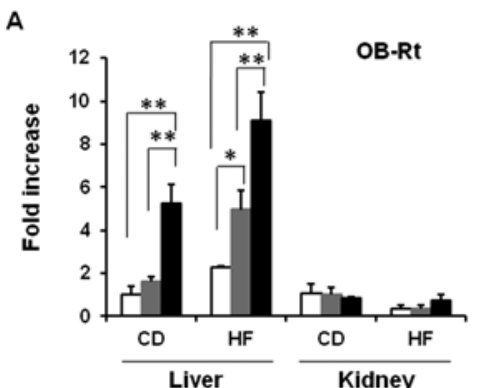

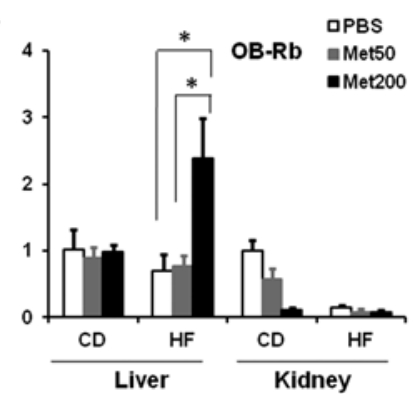
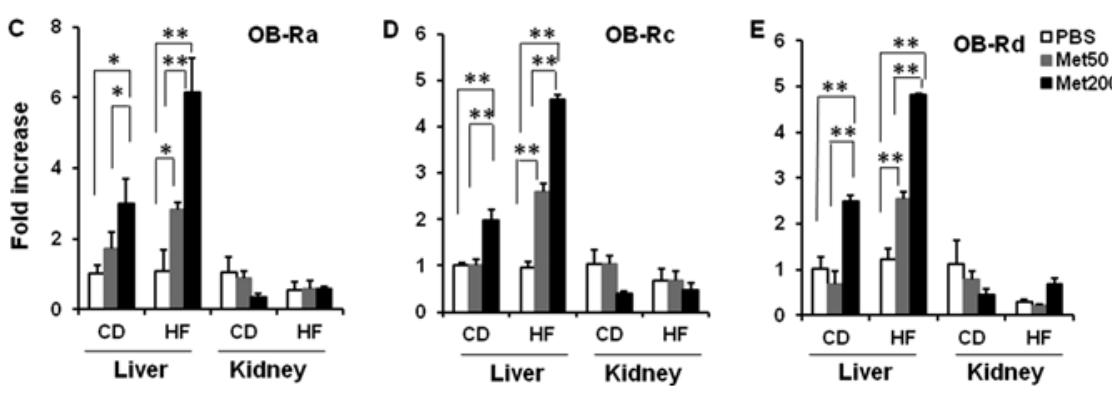

Figure 3

Metformin significantly upregulates the expression of leptin receptors in liver, but not in kidney. The mRNA levels of both long and short leptin receptor isoforms were determined, in the absence or presence of metformin treatment, by real-time PCR using $\beta$-actin as an internal control in liver and kidney from $C D$ or HF mice: $(A)$ total leptin receptor (OB-Rt); (B) OB-Rb; (C) OB-Ra; (D) OB-Rc; (E) OB-Rd. The values are mean \pm s.E.M. $* P<0.05$ and $* * P<0.01$. 
A

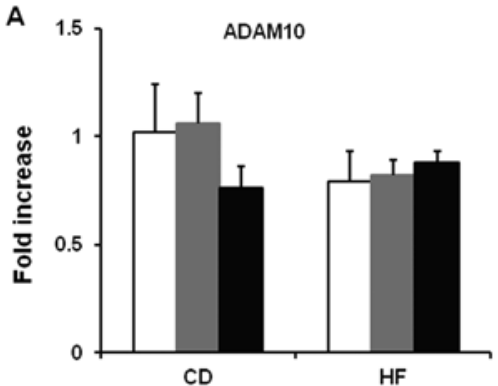

C

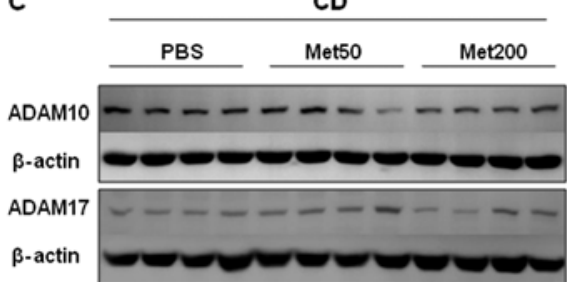

B
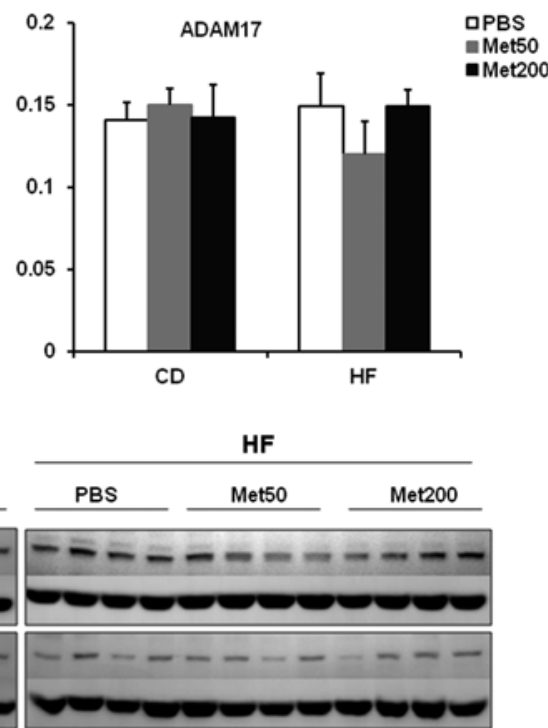

Figure 4

Metformin on expression of sheddases, a disintegrin and metalloproteinase (ADAM)-10 and ADAM-17 in mice liver. The mRNA levels of gene expression were determined by real-time PCR using $\beta$-actin as an internal control: (A) ADAM10; (B) ADAM17 and the protein levels by western blotting in mice liver from control or $\mathrm{HF}$ mice; (C) ADAM10 and (D) ADAM17.

\section{Effect of metformin on liver triglyceride contents and lipogenic gene expressions}

We have previously shown in HepG2 cells that ectopic expression of $\mathrm{OB}-\mathrm{Rb}$ markedly increased leptin signaling activity (Gan et al. 2012), function of which determines hepatic TG accumulation (Fishman et al. 2007). Therefore, we tested TG and cholesterol contents and observed the morphological changes before and after metformin treatment. Histological staining showed that HF induced extensive lipid droplets in hepatocytes (Fig. 5A2), compared with the chow diet mice (Fig. 5A1), and metformin treatment reduced hepatic steatosis (Fig. 5A4 and A6). In consistence, hepatic TG (Fig. 5B) are increased by HF, levels of which are significantly decreased after metformin treatment and with a greater reduction at higher drug dose. Real-time PCR showed that metformin significantly decreases the expression of SREBP-1c (Fig. 5C) and its target lipogenic genes FAS (Fig. 5D) and ACC-1 (Fig. 5E), whereas carnitine palmitoyltransferase-1 (CPT-1) did not show significant change (data not shown).
A

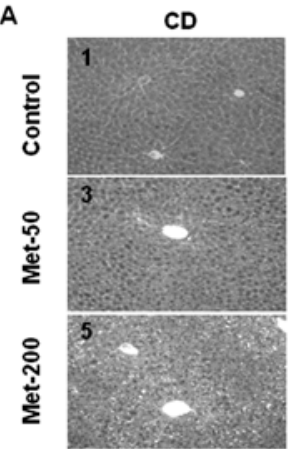

C

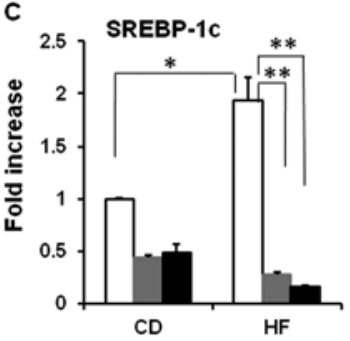

HF

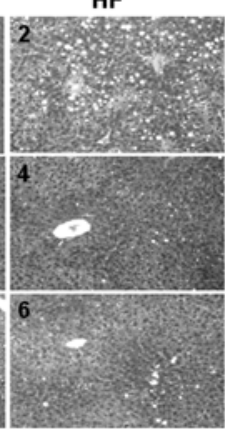

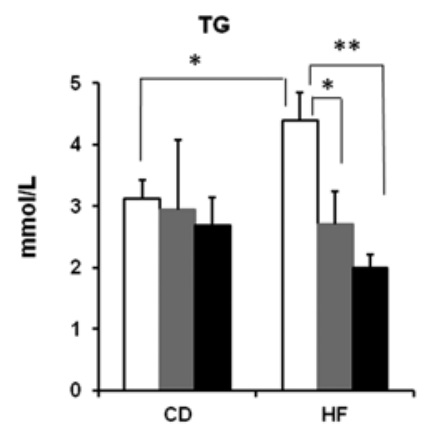

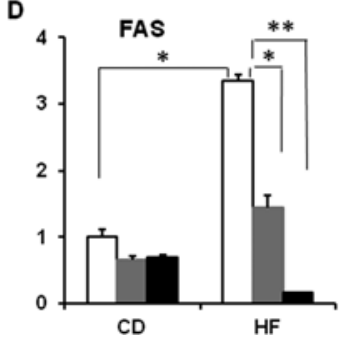

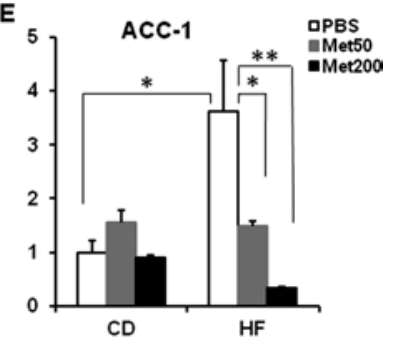

Figure 5

Effect of metformin on liver steatosis, triglyceride contents and lipogenic gene expression (A) Morphology observation of mice liver with $\mathrm{HE}$ staining; (B) contents of triglyceride (TG); (C) the mRNA levels of sterol regulatory element binding protein 1C (SREBP-1C); (D) fatty acid synthase (FAS) and (E) acetyl-CoA carboxylase-1 (ACC-1) in mice liver. http://joe.endocrinology-journals.org
DOI: $10.1530 / J O E-16-0142$
๑) 2016 Society for Endocrinology Printed in Great Britain 


\section{Discussion}

We hereby demonstrated that metformin upregulates plasma sOB-R levels in mice and T2DM patients. This is likely due to metformin-stimulated hepatic expression of leptin receptor, especially the short isoforms (OB-Ra, -Rc and -Rd). The stimulation effect is dose-dependent regardless of diet types (CD or HF) in mice. Long isoform OB- $\mathrm{Rb}$ can also be upregulated by metformin yet at a higher dose. Our findings that metformin treatment increases hepatic leptin receptors and sOB-R levels are new and underscore metformin as leptin sensitizer in liver.

There is numerous evidence showing the beneficial effects of metformin on improving NAFLD phenotypes. The main molecular mediator of these effects is regarded as adenosine monophosphate-activated protein kinase (AMPK) (Browning \& Horton 2004, Woo et al. 2014, Zheng et al. 2015). By activation of AMPK, metformin improved hepatic lipid metabolism via decreasing activities of ACC-1 and hydroxymethylglutarylcoenzyme A (HMG-CoA) reductase, promoting $\beta$-oxidation, and inhibiting SREBP 1-c, a master transcription factor that induces the expression of lipogenic genes including FAS (Li et al. 2011), leading to decreased steatosis levels. In this study, we have shown that metformin upregulates hepatic OB-Rb, suggesting metformin may directly enhance hepatic leptin sensitivity, an action that may contribute to its antisteatotic effects, especially in the context of obesity.

Indeed, leptin is shown to play a major role in deposition of TG in liver. In the absence of functional leptin $(\mathrm{ob} / \mathrm{ob})$ or its receptor $(\mathrm{db} / \mathrm{db})$, mice displayed substantial hepatic steatosis, and leptin replacement or re-expression of leptin receptor in the livers of leptin receptor-deficient Zucker diabetic fatty (ZDF) rats reversed this pathology (Lee et al. 2001). Administration of leptin markedly decreases hepatic TG content (by 63\%, $P<0.05$ ) in normal rats, whereas this effect was abolished in ZDF rats (Fishman et al. 2007). Importantly, mice with ablated hepatic leptin signaling had increased lipid accumulation in the liver (Huynh et al. 2010). Therefore, our result showed that upregulation of hepatic OB-Rb expression under higher metformin dose $(200 \mathrm{mg} / \mathrm{kg} /$ day) (Fig. 3B)is associated with a further reduction in TG content (Fig. 5B) compared with lower dose of metformin $(50 \mathrm{mg} / \mathrm{kg} /$ day $)$ and suggests that enhanced leptin sensitivity may contribute to the this antisteatotic effect. In support, expression of lipogenic genes FAS and ACC-1 shows a further decrease under this condition
(Fig. 5D and E). Although we did not definitely assess signaling pathways downstream of OB-Rb in mediating the lipid-lowering effects in liver, reports indicate that AMPK and signal transducer and activator of transcription 3 (STAT3) are two pathways likely to be involved. In a recent report, adenovirus-mediated liverspecific OB-Rb overexpression has been shown to activate AMPK pathway to reduce lipid synthesis and promote lipid oxidation and eventually resulted in apparent amelioration of hepatosteatosis in mice under HF conditions (Yoshino et al. 2014). Meanwhile, a number of studies showed that deficiency in STAT3, a major signaling pathway downstream of OB-Rb, or its upstream gp130 in hepatocytes exacerbates fatty liver induced by a cholinedeficient, ethionine-supplemented diet (Kroy et al. 2010), alcohol-containing diet (Horiguchi et al. 2008) or highfat diet (Inoue et al. 2004), whereas overexpression of constitutively activated STAT3 ameliorates high-fat dietinduced fatty liver via inhibition of SREBP-1c (Inoue et al. 2004, Kinoshita et al. 2008). Future studies are thus required to clarify the physiological functions of AMPK and STAT3 pathways downstream of leptin/OB-Rb in mediating the antisteatotic effects of metformin in liver.

In this study, we have shown that metformin significantly increases sOBR levels, an effect likely resulted from the increased expression and substrate availability of hepatic leptin receptors (OB-Ra, -Rb, -Rc and -Rd). This is in full agreement with the notion that liver is the main source of plasma sOBR (Cohen et al. 2005). Currently, the biological impact of increased sOB-R levels is still under dispute, due to a comparable binding affinity of leptin to sOBR and its membrane receptor (Lammert et al. 2001). As a consequent, sOB-R may modulate leptin function in bidirectional ways: (1) either as an antagonist by its direct competition for the ligand with its specific membrane receptors (Zastrow et al. 2003; Zhang \& Scarpace 2009) and inhibits leptin transport into the brain (Tu et al. 2008) (2) or as an agonist, via binding leptin, decreases its clearance in circulation and increases its half-life and function (Gavrilova et al. 1997). Accumulating data favor the view that elevated levels of sOBR is a beneficial biomarker for enhanced leptin sensitivity, which is generally associated with energy surplus condition as in obesity. Worth to mention is that increased plasma SOBR levels are also frequently associated with energy-deficient conditions, as is the case for fasting (Chan et al. 2002), food deprivation (Cohen et al. 2005), type 1 diabetes (Kratzsch et al. 2004, Kratzsch et al. 2006), eating disorders such as anorexia nervosa and bulimia nervosa (Monteleone et al. 2002) or catabolic states as in nephritic syndrome

Published by Bioscientifica Ltd. 
(Schroth et al. 2003) and severe malnutrition (Stein et al. 2006). In such conditions, the increased sOBR levels are generally regarded as a compensatory mechanism by which leptin action is antagonized; hence, food intake is promoted and energy consumptions decreased, so as to replenish the body's energy shortage. Here, our data suggest that increased sOBR levels by metformin did not show an enhanced central leptin sensitivity, as our data exhibit no significant reduction in body weight in both mice (data not shown) and T2DM patients (Table 2). This is in discrepancy with previous report where sOBR transgenic mice demonstrated enhanced leptin sensitivity as shown by lower body weight, increased energy expenditure and lower body fat content compared with wild-type mice (Lou et al. 2010). One explanation for this discrepancy may be because the patients who receive metformin treatment and come back for blood testing are not obese (BMI 21.41 \pm 1.386 ) (Table 2), although their body weight, waist circumference and waist-tohip ratio show a tendency of decrease (Table 2), yet not reach a statistical significance. The second explanation may be because the therapeutic time using metformin (1 month in patients and 15 days in mice) may not be long enough to show a distinguishable weight-loss effect. Further studies are required to determine the dose and time effects of metformin on leptin sensitivity in central and peripheral tissues, and should include patients with different degree of obesity.

Worth to mention, it is possible that when combined with additional endocrine abnormalities, the effect of metformin on leptin receptor expression and plasma sOBR levels may be absent or over-ridden. As has been reported previously, 4 months therapy with metformin $(1500 \mathrm{mg}$ daily) in seven obese women with hyperinsulinemia and PCOS did not affect the sOBR levels (Romualdi et al. 2008). It is possible that in the presence of high circulating levels of other hormones, metformin-stimulated signaling pathways are blunted and other regulatory mechanisms become more prominent. Hence, the mechanisms underlying metformin-stimulated leptin receptor gene expression warrant further investigation.

In conclusion, the findings that metformin increases sOBR levels and hepatic leptin receptors including OB-Rb implicate enhanced hepatic leptin sensitivity as an underlying mechanism, mediating its antisteatotic effect. Our study expands current understanding of metformin as leptin sensitizer not only in the brain (Aubert et al. 2011) but also in liver, results of which may provide novel rationale in future clinical uses of metformin in leptin resistance-associated disorders.

\section{Declaration of interest}

The authors declare that there is no conflict of interest that could be perceived as prejudicing the impartiality of the research reported.

\section{Funding}

This work was supported by the National Natural Science Foundation of China (grant numbers 30971082, 81270482).

\section{Author contribution statement}

Xuemei Tang, Jingwen Li, Wei Xiang and Ye Cui conducted the experiments, analyzed the data and drew graphs. Bin Xie, Xiaodong Wang and Zihui Xu contributed to discussion and revised the paper. Lixia Gan designed experiments, wrote the manuscript and takes full responsibility for the present work.

\section{References}

Aubert G, Mansuy V, Voirol MJ, Pellerin L \& Pralong FP 2011 The anorexigenic effects of metformin involve increases in hypothalamic leptin receptor expression. Metabolism 60 327-334. (doi:10.1016/j.metabol.2010.02.007)

Balagopal PB, Gidding SS, Buckloh LM, Yarandi HN, Sylvester JE, George DE \& Funanage VL 2010 Changes in circulating satiety hormones in obese children: a randomized controlled physical activity-based intervention study. Obesity 18 1747-1753. (doi:10.1038/oby.2009.498)

Brabant G, Nave H, Horn R, Anderwald C, Müller G \& Roden M 2004 In vivo and in vitro evidence for a hepatic modulation of the leptin signal in rats. European Journal of Clinical Investigation 34 831-837. (doi:10.1111/j.1365-2362.2004.01427.x)

Browning JD \& Horton JD 2004 Molecular mediators of hepatic steatosis and liver injury. Journal of Clinical Investigation 114 147-152. (doi:10.1172/JCI200422422)

Caro JF, Kolaczynski JW, Nyce MR, Ohannesian JP, Opentanova I, Goldman WH, Lynn RB, Zhang PL, Sinha MK \& Considine RV 1996 Decreased cerebrospinal-fluid/serum leptin ratio in obesity: a possible mechanism for leptin resistance. Lancet 348 159-161. (doi:10.1016/ S0140-6736(96)03173-X)

Chan JL, Blüher S, Yiannakouris N, Suchard MA, Kratzsch J \& Mantzoros CS 2002 Regulation of circulating soluble leptin receptor levels by gender, adiposity, sex steroids, and leptin: observational and interventional studies in humans. Diabetes $512105-2012$. (doi:10.2337/diabetes.51.7.2105)

Clément K, Vaisse C, Lahlou N, Cabrol S, Pelloux V, Cassuto D, Gourmelen M, Dina C, Chambaz J, Lacorte JM, et al. 1998 A mutation in the human leptin receptor gene causes obesity and pituitary dysfunction. Nature 392 398-401. (doi:10.1038/32911)

Cohen P, Yang G, Yu X, Soukas AA, Wolfish CS, Friedman JM \& Li C 2005 Induction of leptin receptor expression in the liver by leptin and food deprivation. Journal of Biological Chemistry $28010034-10039$. (doi:10.1074/jbc.M413684200)

Cohen SE, Kokkotou E, Biddinger SB, Kondo T, Gebhardt R, Kratzsch J, Mantzoros CS \& Kahn CR 2007 High circulating leptin receptors with normal leptin sensitivity in liver-specific insulin receptor knock-out (LIRKO) mice. Journal of Biological Chemistry $\mathbf{2 8 2}$ 23672-23678. (doi:10.1074/jbc.M704053200)

Coleman DL 1982 Diabetes-obesity syndromes in mice. Diabetes 31 1-6. (doi:10.2337/diab.31.1.S1) 
de Luca C, Kowalski TJ, Zhang Y, Elmquist JK, Lee C, Kilimann MW, Ludwig T, Liu SM \& Chua SC Jr 2005 Complete rescue of obesity, diabetes, and infertility in $\mathrm{db} / \mathrm{db}$ mice by neuron- specific LEPR-B transgenes. Journal of Clinical Investigation 115 3484-3493. (doi:10.1172/JCI24059)

Farooqi IS, Wangensteen T, Collins S, Kimber W, Matarese G, Keogh JM, Lank E, Bottomley B, Lopez-Fernandez J, Ferraz-Amaro I, et al. 2007 Clinical and molecular genetic spectrum of congenital deficiency of the leptin receptor. New England Journal of Medicine 356 237-247. (doi:10.1056/NEJMoa063988)

Fishman S, Muzumdar RH, Atzmon G, Ma X, Yang X \& Einstein FH 2007 Resistance to leptin action is the major determinant of hepatic triglyceride accumulation in vivo. FASEB Journal 21 53-60. (doi:10.1096/fj.06-6557com)

Flak JN \& Myers MG Jr 2016 Minireview: CNS mechanisms of leptin action. Molecular Endocrinology 30 3-12. (doi:10.1210/me.2015-1232)

Foretz M, Guigas B, Bertrand L, Pollak M \& Viollet B 2014 Metformin: from mechanisms of action to therapies. Cell Metabolism 20 953-966. (doi:10.1016/j.cmet.2014.09.018)

Gajewska J, Weker H, Ambroszkiewicz J, Szamotulska K, Chełchowska M, Franek E \& Laskowska-Klita T 2013 Alterations in markers of bone metabolism and adipokines following a 3-month lifestyle intervention induced weight loss in obese prepubertal children. Experimental and Clinical Endocrinology \& Diabetes 121 498-504. (doi:10.1055/s-00000017)

Gan L, Guo K, Cremona ML, McGraw TE, Leibel RL \& Zhang Y 2012 TNF- $\alpha$ up-regulates protein level and cell surface expression of the leptin receptor by stimulating its export via a PKC-dependent mechanism. Endocrinology 153 5821-5833. (doi:10.1210/ en.2012-1510)

Gavrilova O, Barr V, Marcus-Samuels B \& Reitman M 1997 Hyperleptinemia of pregnancy associated with the appearance of a circulating form of the leptin receptor. Journal of Biological Chemistry 272 30546-30551. (doi:10.1074/jbc.272.48.30546)

Ge H, Huang L, Pourbahrami T \& Li C 2002 Generation of soluble leptin receptor by ectodomain shedding of membrane-spanning receptors in vitro and in vivo. Journal of Biological Chemistry $27745898-45903$. (doi:10.1074/jbc.M205825200)

Green BD, Irwin N, Duffy NA, Gault VA, O'harte FP \& Flatt PR 2006 Inhibition of dipeptidyl peptidase-IV activity by metformin enhances the antidiabetic effects of glucagon-like peptide-1. European Journal of Pharmacology 547 192-199. (doi:10.1016/j.ejphar.2006.07.043)

Hamnvik OP, Liu X, Petrou M, Gong H, Chamberland JP, Kim EH, Christophi CA, Kales SN, Christiani DC \& Mantzoros CS 2011 Soluble leptin receptor and leptin are associated with baseline adiposity and metabolic risk factors, and predict adiposity, metabolic syndrome, and glucose levels at 2-year follow-up: the Cyprus Metabolism Prospective Cohort Study. Metabolism 60 987-993. (doi:10.1016/j.metabol.2010.09.009)

Horiguchi N, Wang L, Mukhopadhyay P, Park O, Jeong WI, Lafdil F, Osei-Hyiaman D, Moh A, Fu XY, Pacher P, et al. 2008 Cell typedependent pro- and anti-inflammatory role of signal transducer and activator of transcription 3 in alcoholic liver injury. Gastroenterology 134 1148-1158. (doi:10.1053/j.gastro.2008.01.016)

Huynh FK, Levi J, Denroche HC, Gray SL, Voshol PJ, Neumann UH, Speck M, Chua SC, Covey SD \& Kieffer TJ 2010 Disruption of hepatic leptin signaling protects mice from age- and diet-related glucose intolerance. Diabetes 59 3032-3040. (doi:10.2337/db10-0074)

Ikeda T, Iwata K \& Murakami H 2000 Inhibitory effect of metformin on intestinal glucose absorption in the perfused rat intestine. Biochemical Pharmacology 59 887-890. (doi:10.1016/S0006-2952(99)00396-2)

Inoue H, Ogawa W, Ozaki M, Haga S, Matsumoto M, Furukawa K, Hashimoto N, Kido Y, Mori T, Sakaue H, et al. 2004 Role of STAT-3 in regulation of hepatic gluconeogenic genes and carbohydrate metabolism in vivo. Nature Medicine 10 168-174. (doi:10.1038/nm980)
Kastin AJ, Pan W, Maness LM, Koletsky RJ \& Ernsberger P 1999 Decreased transport of leptin across the blood-brain barrier in rats lacking the short form of the leptin receptor. Peptides 20 1449-1453. (doi:10.1016/S0196-9781(99)00156-4)

Kinoshita S, Ogawa W, Okamoto Y, Takashima M, Inoue H, Matsuki Y, Watanabe E, Hiramatsu R \& Kasuga M 2008 Role of hepatic STAT3 in the regulation of lipid metabolism. Kobe Journal of Medical Sciences $\mathbf{5 4}$ E200-E208.

Kratzsch J, Deimel A, Galler A, Kapellen T, Klinghammer A \& Kiess W 2004 Increased serum soluble leptin receptor levels in children and adolescents with type 1 diabetes mellitus. European Journal of Endocrinology 151 475-481. (doi:10.1530/eje.0.1510475)

Kratzsch J, Knerr I, Galler A, Kapellen T, Raile K, Körner A, Thiery J, Dötsch J \& Kiess W 2006 Metabolic decompensation in children with type 1 diabetes mellitus associated with increased serum levels of the soluble leptin receptor. European Journal of Endocrinology 155 609-614. (doi:10.1530/eje.1.02261)

Kroy DC, Beraza N, Tschaharganeh DF, Sander LE, Erschfeld S, Giebeler A, Liedtke C, Wasmuth HE, Trautwein C \& Streetz KL 2010 Lack of interleukin-6/glycoprotein 130/signal transducers and activators of transcription-3 signaling in hepatocytes predisposes to liver steatosis and injury in mice. Hepatology $51463-473$. (doi:10.1002/hep.23322)

Laimer M, Ebenbichler CF, Kaser S, Sandhofer A, Weiss H, Nehoda H, Aigner F \& Patsch JR 2002 Weight loss increases soluble leptin receptor levels and the soluble receptor bound fraction of leptin. Obesity Research 10 597-601. (doi:10.1038/oby.2002.81)

Lammert A, Kiess W, Bottner A, Glasow A \& Kratzsch J 2001 Soluble leptin receptor represents the main leptin binding activity in human blood. Biochemical and Biophysical Research Communications 283 982-988. (doi:10.1006/bbrc.2001.4885)

Lee Y, Wang MY, Kakuma T, Wang ZW, Babcock E, McCorkle K, Higa M, Zhou YT \& Unger RH 2001 Liporegulation in diet-induced obesity. The antisteatotic role of hyperleptinemia. Journal of Biological Chemistry 276 5629-5635. (doi:10.1074/jbc.M008553200)

Leone A, Di Gennaro E, Bruzzese F, Avallone A \& Budillon A 2014 New perspective for an old antidiabetic drug: metformin as anticancer agent. Cancer Treatment and Research 159 355-376. (doi:10.1007/978-3-642-38007-5)

Li Y, Xu S, Mihaylova MM, Zheng B, Hou X, Jiang B, Park O, Luo Z, Lefai E, Shyy JY, et al. 2011 AMPK phosphorylates and inhibits SREBP activity to attenuate hepatic steatosis and atherosclerosis in diet-induced insulin-resistant mice. Cell Metabolism 13 376-388. (doi:10.1016/j.cmet.2011.03.009)

Lou PH, Yang G, Huang L, Cui Y, Pourbahrami T, Radda GK, Li C \& Han W 2010 Reduced body weight and increased energy expenditure in transgenic mice over-expressing soluble leptin receptor. PLOS ONE 5 e11669. (doi:10.1371/journal.pone.0011669)

Maamra M, Bidlingmaier M, Postel-Vinay MC, Wu Z, Strasburger CJ \& Ross RJ 2001 Generation of human soluble leptin receptor by proteolytic cleavage of membrane-anchored receptors. Endocrinology 142 4389-4393. (doi:10.1210/endo.142.10.8442)

Madiraju AK, Erion DM, Rahimi Y, Zhang XM, Braddock DT, Albright RA, Prigaro BJ, Wood JL, Bhanot S, MacDonald MJ, et al. 2014 Metformin suppresses gluconeogenesis by inhibiting mitochondrial glycerophosphate dehydrogenase. Nature $\mathbf{5 1 0}$ 542-546. (doi:10.1038/nature13270)

Maida A, Lamont BJ, Cao X \& Drucker DJ 2011 Metformin regulates the incretin receptor axis via a pathway dependent on peroxisome proliferator-activated receptor- $\alpha$ in mice. Diabetologia 54 339-349. (doi:10.1007/s00125-010-1937-z)

Malin SK \& Kashyap SR 2014 Effects of metformin on weight loss: potential mechanisms. Current Opinion in Endocrinology, Diabetes Obesity 21 23-329. (doi:10.1097/med.0000000000000095)

Marroquí L, Gonzalez A, Neco P, Caballero-Garrido E, Vieira E, Ripoll C, Nadal A \& Quesada I 2012 Role of leptin in the pancreatic $\beta$-cell:

Published by Bioscientifica Ltd 
effects and signaling pathways. Journal of Molecular Endocrinology 49 R9-R17. (doi:10.1530/jme-12-0025)

Miao H, Ou J, Ma Y, Guo F, Yang Z, Wiggins M, Liu C, Song W, Han X, Wang M, et al. 2014 Macrophage CGI-58 deficiency activates ROS-inflammasome pathway to promote insulin resistance in mice. Cell Reports 7 223-235. (doi:10.1016/j.celrep.2014.02.047)

Miller RA, Chu Q, Xie J, Foretz M, Viollet B \& Birnbaum MJ 2013 Biguanides suppress hepatic glucagon signalling by decreasing production of cyclic AMP. Nature 494 256-260. (doi:10.1038/ nature11808)

Misso ML \& Teede HJ 2015 Metformin in women with PCOS, cons. Endocrine 48 428-433. (doi:10.1007/s12020-014-0394-8)

Montague CT, Farooqi IS, Whitehead JP, Soos MA, Rau H, Wareham NJ, Sewter CP, Digby JE, Mohammed SN, Hurst JA, et al. 1997 Congenital leptin deficiency is associated with severe early-onset obesity in humans. Nature 387 903-908. (doi:10.1038/43185)

Monteleone P, Fabrazzo M, Tortorella A, Fuschino A \& Maj M 2002 Opposite modifications in circulating leptin and soluble leptin receptor across the eating disorder spectrum. Molecular Psychiatry $\mathbf{7}$ 641-646. (doi:10.1038/sj.mp.4001043)

Morales DR \& Morris AD 2015 Metformin in cancer treatment and prevention. Annual Review of Medicine 66 17-29. (doi:10.1146/ annurev-med-062613-093128)

Muoio DM \& Lynis Dohm G 2002 Peripheral metabolic actions of leptin. Best Practice \& Research Clinical Endocrinology \& Metabolism 16 653-666. (doi:10.1053/beem.2002.0223)

Myers MG Jr, Leibel RL, Seeley RJ \& Schwartz MW 2010 Obesity and leptin resistance: distinguishing cause from effect. Trends in Endocrinology and Metabolism 21 643-651. (doi:10.1016/j.tem.2010.08.002)

Ogawa T, Hirose H, Yamamoto Y, Nishikai K, Miyashita K, Nakamura H, Saito I \& Saruta T 2004 Relationships between serum soluble leptin receptor level and serum leptin and adiponectin levels, insulin resistance index, lipid profile, and leptin receptor gene polymorphisms in the Japanese population. Metabolism 53 879-885. (doi:10.1016/j.metabol.2004.02.009)

Romualdi D, Campagna G, Selvaggi L Jr, Cento R, Proto C, Lanzone A \& Guido M 2008 Metformin treatment does not affect total leptin levels and free leptin index in obese patients with polycystic ovary syndrome. Fertility and Sterility 89 1273-1276. (doi:10.1016/j.fertnstert.2007.05.004)

Schaab M, Kausch H, Klammt J, Nowicki M, Anderegg U, Gebhardt R, Rose-John S, Scheller J, Thiery J \& Kratzsch J 2012 Novel regulatory mechanisms for generation of the soluble leptin receptor: implications for leptin action. PLOS ONE 7 e34787. (doi:10.1371/ journal.pone.0034787)

Schroth M, Kratzsch J, Gröschl M, Rauh M, Rascher W \& Dötsch J 2003 Increased soluble leptin receptor in children with nephrotic syndrome. Journal Clinical Endocrinology and Metabolism $\mathbf{8 8}$ 5497-5501. (doi:10.1210/jc.2003-030539)

Shin NR, Lee JC, Lee HY, Kim MS, Whon TW, Lee MS \& Bae JW 2014 An increase in the Akkermansia spp. population induced by metformin treatment improves glucose homeostasis in diet-induced obese mice. Gut 63 727-735. (doi:10.1136/gutjnl-2012-303839)

Siejka A, Jankiewicz-Wika J, Kołomecki K, Cywiński J, Piestrzeniewicz K, Swiętosławski J, Stępień H \& Komorowski J 2013 Long-term impact of vertical banded gastroplasty (VBG) on plasma concentration of leptin, soluble leptin receptor, ghrelin, omentin-1, obestatin, and retinol binding protein 4 (RBP4) in patients with severe obesity. Cytokine 64 490-493. (doi:10.1016/j.cyto.2013.07.026)

Stein K, Vasquez-Garibay E, Kratzsch J, Romero-Velarde E \& Jahreis G 2006 Influence of nutritional recovery on the leptin axis in severely malnourished children. Journal Clinical Endocrinology and Metabolism 91 1021-1026. (doi:10.1210/jc.2005-1394)

Sun Q, van Dam RM, Meigs JB, Franco OH, Mantzoros CS \& Hu FB 2010 Leptin and soluble leptin receptor levels in plasma and risk of type 2 diabetes in U.S. women: a prospective study. Diabetes 59 611-618. (doi:10.2337/db09-1343)

Tu H, Kastin AJ, Hsuchou H \& Pan W 2008 Soluble receptor inhibits leptin transport. Journal of Cellular Physiology 214 301-305. (doi:10.1002/jcp.21195)

Wolfe BE, Jimerson DC, Orlova C \& Mantzoros CS 2004 Effect of dieting on plasma leptin, soluble leptin receptor, adiponectin and resistin levels in healthy volunteers. Clinical Endocrinology $61332-338$. (doi:10.1111/j.1365-2265.2004.02101.x)

Woo SL, Xu H, Li H, Zhao Y, Hu X, Zhao J, Guo X, Guo T, Botchlett R, Qi T, et al. 2014 Metformin ameliorates hepatic steatosis and inflammation without altering adipose phenotype in diet-induced obesity. PLOS ONE 9 e91111. (doi:10.1371/journal.pone.0091111)

Yoshino S, Satoh T, Yamada M, Hashimoto K, Tomaru T, Katano-Toki A, Kakizaki S, Okada S, Shimizu H, Ozawa A, et al. 2014 Protection against high-fat diet-induced obesity in Helz2-deficient male mice due to enhanced expression of hepatic leptin receptor. Endocrinology 155 3459-3472. (doi:10.1210/en.2013-2160)

Yu D, Yu Z, Sun Q, Sun L, Li H, Song J, Mi M, Wu H, Lu L, Liu C, et al. 2011 Effects of body fat on the associations of high-molecular-weight adiponectin, leptin and soluble leptin receptor with metabolic syndrome in Chinese. PLoS ONE 6 e16818. (doi:10.1371/journal. pone.0016818)

Zastrow O, Seidel B, Kiess W, Thiery J, Keller E, Böttner A \& Kratzsch J 2003 The soluble leptin receptor is crucial for leptin action: evidence from clinical and experimental data. International Journal of Obesity and Related Metabolic Disorders 27 1472-1478. (doi:10.1038/ sj.ijo.0802432)

Zhang J \& Scarpace PJ 2009 The soluble leptin receptor neutralizes leptin-mediated STAT3 signalling and anorexic responses in vivo. British Journal of Pharmacology 158 475-482. (doi:10.1111/ j.1476-5381.2009.00246.x)

Zhang Y, Proenca R, Maffei M, Barone M, Leopold L \& Friedman JM 1994 Positional cloning of the mouse obese gene and its human homologue. Nature 372 425-432. (doi:10.1038/372425a0)

Zheng J, Woo SL, Hu X, Botchlett R, Chen L, Huo Y \& Wu C 2015 Metformin and metabolic diseases: a focus on hepatic aspects. Frontiers of Medicine 9 173-186. (doi:10.1007/s11684-015-0384-0)

Received in final form 19 May 2016

Accepted 8 June 2016

Accepted Preprint published online 9 June 2016 http://joe.endocrinology-journals.org

DOI: 10.1530/JOE-16-0142
๑) 2016 Society for Endocrinology Printed in Great Britain
Published by Bioscientifica Ltd 